\title{
FURTHER \\ DEVELOPMENT OF CONTRAST MEDIA
}

The development of $\mathrm{CM}$ aims at further improvement of tolerance and identification of new diagnostic options by altering pharmacokinetic properties. New technical developments of imaging modalities also influence the use of and need for $\mathrm{CM}$ with special properties.

It is expected that established state-of-the-art radiological techniques will be developed further, expanding current uses towards the examination of larger volumes, more rapid sequences, and lower radiation exposure. The standard radiological methods will retain their current role.

It will be hard to surpass the level of efficacy, tolerance and safety of current contrast media while simultaneously keeping the cost of products at an acceptable level. 
New approaches in X-ray contrast medium research have evolved from studies with metal ion chelates for magnetic resonance imaging [107]. Heavy elements absorb X-rays more effectively than iodine but are much more difficult to bind to organic, well-tolerated and excretable substances in a suitable form. Initial clinical applications suggest the suitability of chelates for X-ray techniques but safety issues remain to be solved [108, 109].

New technical developments will further expand and modify the diagnostic possibilities in the years to come. Dynamic, physiologically controlled and high-resolution scanners improve detail resolution in CT, and very fast scanners allowing coverage of very large volumes with very short scan times are currently being introduced into clinical practice.

With the rapid infusion of well-tolerated $\mathrm{CM}$, even better information on tissue perfusion, capillary permeability and the extracellular space of tissues can be obtained.

Open Access This chapter is licensed under the terms of the Creative Commons Attribution 4.0 International License (http://creativecommons.org/licenses/by/4.0/), which permits use, sharing, adaptation, distribution and reproduction in any medium or format, as long as you give appropriate credit to the original author(s) and the source, provide a link to the Creative Commons license and indicate if changes were made.

The images or other third party material in this chapter are included in the chapter's Creative Commons license, unless indicated otherwise in a credit line to the material. If material is not included in the chapter's Creative Commons license and your intended use is not permitted by statutory regulation or exceeds the permitted use, you will need to obtain permission directly from the copyright holder.

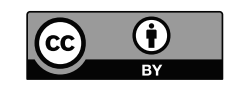

